ACTA UNIVERSITATIS LODZIENSIS

FOLIA LITTERARIA POLONICA 2(40) 2017

http://dx.doi.org/10.18778/1505-9057.40.03

Marta Koronkiewicz

\title{
Politics of the Poetic Form: Adam Ważyk and the Americans ${ }^{1}$
}

What are the capabilities of the poetic form? Why is it through the form that the poetics become politics become poetics again? The relationship between the formal and the political in literature - oft ignored by the mainstream critics and more conservative academics alike - has constantly drawn the attention of various progressive poets, writers and critics of all cultures and languages. In the English-speaking world, one can try and sketch out a loose continuity, a quasitradition of great Marxist poets whose critical writings focused on the performative and political potential of the literary form. In the post-war American poetry, this tradition would certainly include such otherwise diverse authors as Muriel Rukeyser, Adrienne Rich, James Scully, or Ron Silliman. The purpose of this paper is to offer a Polish perspective of sorts - and to show that Adam Ważyk, a Polish poet of a similar theoretical sensitivity and political background, shared with his American colleagues a lot of the same instincts and intuitions, all despite the significant geopolitical distance between them. This cross-cultural connection was made possible largely due to a certain practical approach common among the radical progressive poets, i.e. their focus on the immediate performative potential of the literary form rather than its broader theoretical context.

$$
* \quad * \quad *
$$

The relationship between Marxism and formalism has always been a notoriously complicated one. Although one could expect Marxist thinkers and academics to be among the first to appreciate poetry and literature as tools for social change, the radical left has been traditionally accused of treating the literary form as a mere derivative of social changes, an epiphenomenon of various socio-cultural forces.

* Dr; University of Wrocław, Faculty of Philology, Institute of Polish Studies; pl. Nankiera 15, 50-140 Wrocław; m.e.koronkiewicz@gmail.com.

${ }^{1}$ Tekst powstał w ramach pracy nad projektem grantowym "Nauka chodzenia". Świadomość późnonowoczesna $w$ metapoetyckich wypowiedziach przedstawicieli polskiej neoawangardy lat 60. i 70. XX wieku (11H 130651 82) 0064/NPRH3/H11/82/2014. 
Today this criticism is particularly vivid in countries such as Poland, where, due to obvious historical reasons, Marxist-influenced critics and authors can still be suspected of authoritarian sympathies.

Nonetheless, the general epiphenomenal approach may be usually reduced to one of two different subtypes or specific frameworks. Within the first one, the work of literature is seen as a reflection and/or a tool in the service of the ideological narrative. In this model, literature remains a passive offspring of ideology, while the literary form remains a vehicle for a message that's been formulated elsewhere. In Poland, in recent years such accusations have been made against such left-leaning authors as Igor Stokfiszewski or Przemysław Czapliński².

The second approach assumes that this connection is less immediate - it's not about a particular work directly mirroring a certain aspect of the ideological narrative; rather than that, it's literature in general (as a social construct etc.) that follows a set of inherently non-literary laws. And so, the history of literature, the evolution of genres etc. are seen as either closely following the broader socio-cultural patterns, or they are at least believed to be predictable through non-literary means, such as sociological and anthropological concepts, political economy or game theory. Notably, among the Marxist thinkers accused in recent years of overreliance on this framework was Franco Moretti, due to his suggestion that the theory of evolution can be used to further our understanding of the evolution of various literary forms ${ }^{3}$.

Although the epiphenomenal approach (in both of its basic forms) has rarely been taken to its rather caricatural extremes, it's nonetheless one of the main reasons why it's so common to accuse Marxist scholars of treating literature as a mere instrument, a puppet in the hands of the external, non-literary, political agents.

And, however unfair and biased many of these accusations may seem, they sometimes stem from an honest and well-founded concern. The best of the Marxist literary theorists - from Fredric Jameson to Raymond Williams - have, of course, written extensively about specific texts in all of their singular, autonomous, performative potential. Nonetheless, many Marxist thinkers seem to share a sort of a deeper belief, an internalised conviction that the literary remains firmly rooted in what is already present in the world; that it is, in other words, bound to

${ }^{2}$ I.e. I. Stokfiszewski, Zwrot polityczny, Krytyka Polityczna, Warszawa 2009; P. Czapliński, Polska do wymiany. Późna nowoczesność i nasze wielkie narracje, W.A.B., Warszawa 2009; Polityka literatury. Przewodnik krytyki politycznej, [K. Dunin et al., introduction P. Czapliński], Krytyka Polityczna, Warszawa 2009. Further reading on the debate: D. Kozicka, Krytyki literackiej kłopoty z politycznościa (w ostatnim 20-leciu), "Pamiętnik Literacki" 2009, issue 100/2, pp. $125-144$.

${ }^{3}$ F. Moretti, Graphs, Maps, Trees. Abstract Models for Literary History, Verso, London-New York 2007; F. Moretti, Distant Reading, Verso, New York 2013. 
comment on reality as it already exists, that its task is more to report on what's out there than to design a different future. In the words of Tony Bennett, "Within historically orientated schools of criticism, the text is construed as being, in some sense, a record of the period to which it refers" logical rule, this approach remains a part of a general sensitivity present in the work of various Marxist theorists.

One could say that all of this stems directly from the issue of scope. Marxist theorists tend to operate on a macroscale of sorts - when discussing form, they usually focus on its "large" units and broad processes (see, again, Moretti, at least before his The Bourgeois): whole genres, conventions, historical turns, phenomena observable within the longue durée perspective. This is true for those with background in anthropology, like Williams; in cultural criticism, like Jameson; and in philosophy, like Eagleton.

One can find an interesting attempt to subvert the epiphenomenal strategy in a classic work by Tony Bennett - who, despite his contribution to the Marxist theory, remains little known outside the left-leaning academic circles - namely, Formalism and Marxism from 19795. There, Bennett proposes that the literary critics shift their focus away from the realm of "aesthetics" and towards "politics", by forging a new Formalist-inspired idea of literature. Contrary to popular intuitions, Bennett saw literary form not as an anchor of sorts, keeping the entire literary field firmly rooted in the traditional aesthetics, but as a means of emancipating the whole field and moving it decisively towards the living fabric of social life; for Bennett, appreciating the formal aspects of a literary work meant moving away from aesthetics rather than further towards $\mathrm{it}^{6}$. In other words, recapturing the formalism for the purposes of Marxist criticism - the main explicit purpose of Bennett's work - would, quite paradoxically, require that we abandon the field of aesthetics. And though even today Bennett's project may provide progressive critics with interesting questions and concepts, the contemporary academic discourse on literary form tends to focus on subverting and going beyond the very opposition of aesthetics and politics.

$$
* \quad * \quad *
$$

This is where it becomes necessary to differentiate between the Marxist literary theory and the Marxist literary criticism, with people like Fredric Jameson or Franco Moretti on the one side, and those with a more practical approach to

${ }^{4}$ T. Bennett, Formalism and Marxism, Methuen, London 1979, p. 159.

${ }^{5}$ Ibidem.

${ }^{6}$ Ibidem, p. 3: "We hope, in part, to remedy this by proposing, on the basis of a critical re-examination of the work of the Formalists, a new set of concerns for Marxist criticism, a new concept of 'literature', which will shift it from the terrain of aesthetics to that of politics where it belongs". 
literary form - think poets-turned-critics, like Adrienne Rich, James Scully or Ron Silliman - on the other. Although these two groups obviously share many insights and intuitions, and indeed tend to overlap in many ways, they differ precisely when it comes to the issue of literature as an epiphenomenon. For those with a more practical attitude, poets and critics, the focus is always on the belief that every literary work may actually attempt to overturn its status as a mere epiphenomenon; that by default, a literary text is capable of introducing something completely new into this world. In other words, from the point of view of these critics and practicing poets, the literary text - thanks to its exceptional, unique formal traits and properties - is, first and foremost, something that performs, it retains an ability to cause a change in the world, thanks to the complex mechanisms of its "work".

Sometimes explicitly, sometimes indirectly, authors like Scully or Rich assume and then emphasize the poem's ability to "imagine" or "invent" another reality, its potential to initiate resistance, to transform social relations, shape people's desires and expectations, etc. ${ }^{7}$

The differences between Marxist theory and criticism might, to a certain degree, be reduced to the differences between theory and criticism in general: those who deal with contemporary, living, dynamic phenomena, such as new literature in general, don't necessarily have tools necessary to analyze these phenomena in a longue durée perspective. On the other hand, they traditionally have direct influence on the work of their colleagues and contemporaries; in other words, unlike most theorists, they're able to shape - through discussions, ad hoc criticism and collective work - the new literature as it comes into being, in the most spontaneous, immediate manner.

There is therefore a significant difference of scope or scale: dealing mainly with the works that still haven't been properly received by the public, that are yet to be discussed and digested within the academia, critics feel somehow obliged to pay closer attention, to constantly reduce the distance between themselves and the criticized work. Consequently, they see the new literature in all of its living, dynamic singularity rather than just its epiphenomenal nature.

In this case, the microscale is the level of singular, specific, nuanced formal choices; the realm of particular rhetorical concepts and figures of speech, whose performative potential is yet to be discovered and discussed. It is on this level that the relationship between poetic form and progressive politics has drawn the attention of authors such as Rich, Scully or Silliman. In this context, they shared their interests and intuitions with Adam Ważyk - a Polish poet, translator and one

${ }^{7}$ I.e. A. Rich, Poetry and Commitment. An Essay, W.W. Norton \& Company, London-New York 2007; J. Scully, Line break. Poetry as social practice, Curbstone Books 2005; R. Silliman, The New Sentence, Roof Books, New York 2003. 
of the most influential poetics experts in the history of post-war Polish literature. Throughout his work, Ważyk was primarily interested in the practical link between the literary form and what he saw as progressive politics, which caused him to stand out among the Polish socialist-realist poets and writers. Whereas his colleagues tended to see socialist-realist theory and doctrine in more abstract and/or propagandist terms, Ważyk sought to transpose the principles of Marxist politics onto the level of specific formal choices.

One way to illustrate his approach is through the issue of enjambment. As Ważyk put it in 1964:

[When encountering an enjambment] every reader needs to decide, on his or her own, what to choose, what approach to adopt when reading the poem out loud; some will go for a middle-road of sorts, a fluid narrative. The contradictions introduced by enjambment can be solved and reconciled only by the reader's voice, and they should never be included in a description of the poem's content. An outside observer who chooses to emphasize the tension (or a lack thereof) mistakes his own wishes for the poem's reality; from the readers' point of view, he remains (albeit unconsciously) a sort of an ill-advised stage director with a tendency to overmanagement ${ }^{8}$.

And then, in Amfion: "We know what functions the enjambment cannot have - it cannot evoke peace, agreement, harmony, because in its very essence it remains a discord, a disagreement, a disharmony"9.

The enjambment remains crucial; its first appearance marks the moment when the poem opens itself to the reader, and to the possibility of a reader-driven performance or work. Enjambment remains essentially non-complacent; it is an emblem of poetry's unpredictability, and an ever-present reminder of the social function of the poem.

Enjambment is a particular instance of the line break, which remains (at least in the case of a free verse poem) the only indicator of the poetic nature of a literary work. And so, Ważyk's ideas bear a striking resemblance to some of the concepts developed in one of James Scully's most influential works:

The simplest decisions about the line breaks will ramify, affecting not only the structural economy of a poem but its social practice, the way it works as a poem. For instance, we know that a line break will influence the way a word or syllable is attacked (in the sense that a musician attacks a note). But the difference between one possible line break and another determines more than whether a particular word is taken in stride or "happened upon". The difference affects not only the work's

\footnotetext{
${ }^{8}$ A. Ważyk, Esej o wierszu, Czytelnik, Warszawa 1964, p. 35.
}

${ }^{9}$ A. Ważyk, Amfion, Czytelnik, Warszawa 1983, pp. 50-51. 
internal relation, how as an object it is constructed, but its social practice. When line breaks are shifted, posture and attitude change, along with assumptions about meaning, focus and expectations. The poem "plays" differently ${ }^{10}$.

Similarly to Ważyk, Scully believes that the choice of a particular form is in fact an attempt to solve certain problems through and within the poem:

Writers in their writing practices attempt to solve those problems they have set for themselves, but set in concert with their historical circumstances, social values, class outlook, jobs and the innumerable opaque or transparent 'aesthetic' or 'extra-aesthetic' encouragements and discouragements visited on them. For writers as writers the strict intramural question will be whether the their technical capabilities have risen to the occasions of those problems: problems that are multifaceted, complex, involving more than immaterial linguistic equations ${ }^{11}$.

And so, the poem takes it final form through the work of solving problems. It preserves in itself both the process and the result of this problem-solving; they all define the way in which a poem itself works. Poems exist through and because of their internal tensions; the work of overcoming these tensions is what provoked Adrienne Rich to make the question "Does this poem work?" a central point of her seminal manifesto ${ }^{12}$.

This question has an obviously double meaning. First, it asks about the poem's goals, and its ability to achieve them; but then, there's the question of the poetry's material and performative potential, its ability to "do" something in the world around it, to surpass its status as a static object. The ambivalence of Rich's phrase - which invokes both the idea of the possibility of a formal "success" in literature and the desire for the poem to become something more than just a piece of finished writing - is the organizing principle of her thought. Rich asks about the ways and means through which the poem performs a certain job (or through which it achieves its goals): "What's pushing the grammar and syntax, the sounds, the images - is it the constriction of literalism, fundamentalism, professionalism - a stunted language? Or is it the great muscle of metaphor, drawing strength from resemblance in difference? The great muscle of the unconstricted throat?"13.

\footnotetext{
${ }^{10}$ J. Scully, Line break..., p. 129.

${ }^{11}$ Ibidem.

12 A. Rich, Poetry and Commitment. An Essay, p. 24.

${ }^{13}$ Ibidem, pp. 32-33.
} 
Another formal device that might give us more insight into the nature of the work performed by the poem itself is juxtaposition; a device which, on a very basic level, remains a figure of tension as such. By bringing together two contrasting images or elements, it radically reduces the possibility of a smooth transition, it becomes an expression of urgency and friction; the poem is put into an alert state of sorts, a state of heightened activity. Juxtaposition itself is, in fact, an action in the temporal/musical sense; Ron Silliman reminds us about it in his Z-sited Path, in the context of Zukofsky's comments on Apollinaire, one of the great masters of juxtaposition. Composition is action ${ }^{14}$; juxtaposition is an action that could not be predicted within any of the traditional frameworks or patterns.

For Ważyk - a modernist poet and a great defender of juxtaposition as the most important poetic innovation of his times - juxtaposition-as-action served as an inherently materialist means of social criticism. It allows the poet to effectively perform the crucial act of revising and reevaluating the everyday life of the "habitual connections that the popular sense imposes on us, of the connections that we inherit from our culture, and especially of the stale literary conventions"15. Ważyk develops this thought further:

The flow of the thought, the reasoning - it has all been reduced or even suspended in favor of the narrative and descriptive elements, in favor of a vision that would represent both the internal and the external world. As a result, the causal relationships have been weakened or abandoned altogether in favor of a free flow of facts, a coincidence of events or visions which some tried to attribute to a lack of logic. This tendency, this process remained understandably inimical towards all sorts of generalizing reflection, towards universal categories and abstract ideas. [...] The work of the intellect, if we could call it that, has moved into the vision itself ${ }^{16}$.

The concept of habit ties the issues of the everyday life to the issues of the poetic form. In both those realms it's the breaking down of the habitual ties that brings in genuine innovations. The destruction of these ties was supposed to help reinvigorate the poetic perspective, to abolish the idea of "proper" poetic connections and "accurate" causal chains. The poem itself was supposed to undertake the work of the general intellect. Once again, we are reminded of Rich's idea of a "working poem", and of its desire not to become a mere instrument of someone else's will: "Poetry is not a healing lotion, [...], a kind of linguistic aromatherapy. Neither is it a blueprint, nor an instruction manual"17.

\footnotetext{
${ }^{14}$ R. Silliman, The New Sentence..., p. 143.

${ }^{15}$ A. Ważyk, Dziwna historia awangardy, Czytelnik, Warszawa 1976, p. 80.

${ }^{16}$ Ibidem, p. 78.

${ }^{17}$ A. Rich, Poetry and Commitment, p. 25.
} 
The purpose of the poem's work is, as Rich states in one of the most quoted pieces from Poetry and Commitment, to "remind us of something we are forbidden to see. A forgotten future"18. This ostensibly contradictory term invokes categories such as imagination and desire - ideas central to Rich's critical and literary project. As she also states: "The imagination's road open before us, giving the lie to that slammed and bolted door, that razor-wired fence, that brute dictum: «there is no alternative»" 19 .

The sense that there's no alternative is reinforced by habitual connections, customs and conventions, linguistic automatisms. For Rich only the true awakening of desires might awake the individual, pull her out of the automatism-induced numbness, liberate her from the illusion that there are no alternatives. The awakening of desire is the fundamental purpose of the poem's work; and what it means, in more empirical terms, is actually pretty specific - it's all about the reestablishment of collective literary imagination:

A revolutionary poem will not tell you who or when to kill, what and when to burn, or even how to theorize. It reminds you (for you have known, somehow, all along, maybe lost track) when and where and how you are living and might live - it is a wick of desire. [...] And truly revolutionary art is an alchemy through which waste, greed, brutality, frozen indifference, "blind sorrow", and anger are transmuted into some drenching recognition of the What if? - the possible ${ }^{20}$.

Of course, habits and routines are not necessarily - not always - a bad thing. In his theoretical reflection on these basic elements of our daily lives, Ben Highmore, one of the leading scholars in the field of everyday life studies, emphasized their internal contradictions: the irresolvable tension between the sense of security and frustration, between the routine's ability to soothe one's worries and to make us numb and exhausted ${ }^{21}$. This ambivalence remains the hidden meaning of all routines and habits; it allows us to distinguish them from those deeply internalized automatisms that don't seem to have any positive and/or autonomous meaning - bodily and linguistic conventions that remain essentially invisible and serve only to reinforce status quo by imposing it on individual bodies.

$$
* \quad * \quad *
$$

${ }^{18}$ Ibidem, p. 36.

${ }^{19}$ Ibidem, p. 21.

${ }^{20}$ A. Rich, What is found there? Notes on Poetry and Politics, W.W. Norton \& Company, London-New York 1993, p. 241.

${ }^{21}$ B. Highmore, Homework: routine, social aesthetics and the ambiguity of everyday life, "Cultural Studies" 2014, 18 (2-3), pp. 306-327. 
The relationship between form, work and poetic innovation is one of the main topics of Ron Silliman's work. Referencing Walter Benjamin and the work of Laura Riding, he notes that the very idea of innovation in poetry is made possible by the status of the poem as a product but not a commodity. In the modern society form is seen as an index of labor; the more the given product looks like the previous one, the more inclined we are to think that less labor/effort was put into its creation. By shifting the focus within the relationship between creative work and form we establish the notion of style; form becomes an issue of packaging rather than structure. In our pursuit of innovation, it's easy to mistake this superficial novelty for the true structural change: "the majority of cars simply look new, as do the majority of poems" 22 . These comments bear clear resemblance to the kind of warnings that Ważyk issued in the 40s while addressing the poets of the younger generation; he devoted a large part of his essay on Mayakovsky to this precise issue. According to Ważyk, the real innovation stems from a truly new way of looking at things, where the form can no longer be easily distinguished from the content of the poem. This sort of a poetological, or versological gaze, seeks to discover through the poem new possible forms of social life:

Whether we talk about language, or just the content of the work, in the end it's the same. The content is contained within language. The poet of the innovative form is always, although not always in an equal manner, a poet of innovative content. Mayakovsky's poetic language articulated specific facts, which were often brought into the poem from the realm of economy, where the poet saw a broad current of revolutionary struggle, work and pathos. Drawing from this content, and this word-matter, Mayakovsky set for himself goals that had never been seen in poetry before ${ }^{23}$.

What Ważyk has to say about Mayakovsky is precisely the kind of thing that Mayakovsky would like to hear; he famously wanted to be seen as a "workerpoet", someone who works with and in the word. The work Ważyk sought to undertake was the one Adrienne Rich wrote about - the work of opening up of the new futures and visions, breaking and abolishing of the old habits:

A truly innovative poet tries to get ever closer to the living speech, the colloquial language that the old aesthetics are simply scared about. His fight is necessarily one of words, of language, because the poetry consists of words, but at the same time it's about something bigger: behind the word-matter, behind the syntax and the form of the poem, there is always a certain reality of imagination, concepts and feelings. But if this reality is not expressed through new forms - including ones that only yesterday

${ }^{22}$ R. Silliman, The New Sentence, p. 61.

${ }^{23}$ A. Ważyk, W stronę humanizmu, Książka - Spółdzielnia Wydawnicza, Warszawa 1949, p. 60. 
were still considered prosaic rather than poetic - the mere mention of some other, imaginary reality is bound to remain just a declaration of one's own finesse - which stands in stark contrast to the true innovation ${ }^{24}$.

According to Ważyk, the introduction of "prosaisms" into the poem is a necessary drive behind poetic innovation; all truly innovative poetry, starting with Rimbaud and Baudelaire, had to face accusations of "not being poetry at all". As Ważyk observed in The Argument about Poetry, swear words and obscenities, considered inherently non-poetic before the war, were to become completely acceptable just a few years later. And so, in 1946 Ważyk predicted that the next breakthrough would be the reconciliation of poetry with the language of politics, or social thought. That's why he remained constantly impressed by what he considered an almost impossible feat in the work of Mayakovsky, namely - his ability to introduce pathos, or the sense of social grandeur, into the poem:

The lonely preacher becomes the tribune of the people, and he can feel all the weight of living history right behind him. Overcomplicated, garish metaphors have given place to the rhetoric of large numbers and grand comparisons. What has been liberated is the hyperbole - the desire for pathos, of which there was not enough in the old world, but of which there is plenty in the new reality ${ }^{25}$.

The preacher and the tribune - these are the figures of biased, or tendentious poetry, of poems that have been used as instruments. James Scully wrote extensively about this particular type of poetry, distinct in its "moralising", didactic tone that's eager to judge and set terms. According to Scully, many modern poets consider this tone both irreconcilable with good taste and deeply unethical - as a rule of thumb, poets are not supposed to tell people what they should think or believe in. To maintain otherwise is an assault on both art and humanity as such ${ }^{26}$.

Scully accepts that such beliefs are common, but he's also highly sceptical of their true origins and purpose: in whose interest are such ideas being spread? Thus, quite unexpectedly, he actually decides to defend this sort of biased, tendentious, instrumentalised poetry; contrary to a popular belief, he finds within it a cultural practice that manages to remain a constant challenge to our linguistic habits.

The majority of readers tends to outright reject the words of those who choose to speak as tribunes and prophets; and, just like Ważyk predicted, they're likely to accuse such poets of not writing real poetry at all. If Ważyk and Scully seem

\footnotetext{
${ }^{24}$ Ibidem, p. 57.

${ }^{25}$ Ibidem, p. 55.

${ }^{26}$ J. Scully, Line break..., p. 65.
} 
to value this kind of poetry highly - if they openly praise the poets who dare to be biased and tendentious - it's not because of the type of message those poets convey, but because of their talent for true innovation, the challenge they pose to the poetic form; a true poetic innovation being understood here, once again, as a broadening of our idea of what constitutes "poetry" by means of introduction (or indeed reintroduction) into the poetic language of certain tones, styles and figures that have been previously deemed inherently "non-poetic".

Ważyk recognised that, historically, Polish poetry has always struggled to come to grips with pathos and the sense of social grandeur in general. This is probably the main reason why he repeatedly invoked Walt Whitman as a proposed spiritual guide for the young generation of Polish poets. Ważyk believed that Whitman had already brought us (through the work of the Whitman-influenced Skamander group) the free verse poem and a certain democratic, egalitarian sensitivity; what remained to be discovered was his ability to convey a certain sense of collective, politically motivated ecstasy, to open up the poetic language and form so they can embrace a certain kind of productive pathos.

Authors such as Adrienne Rich, James Scully or Ron Silliman can by no means be seen as members of a unified "school"; what links them together is - first and foremost - shared intuitions, beliefs and insights, as well as, sometimes, personal friendships. Adam Ważyk, in turn, belonged to an older generation of poets; and the sheer geographical distance that separated him from his American colleagues cannot be overlooked. However, if we choose to read their work in parallel - if we see all these authors as members of a certain hidden tradition, linked together by their practical approach to the issues of poetic form - we will find that their thoughts on poetic innovation and the work of the poem complement one another; and that this joint critical project, although never explicitly articulated, may even today renew the way we think about the relationship between aesthetics and progressive politics.

\section{Bibliography}

Bennett Tony, Formalism and Marxism, Methuen, London 1979.

Czapliński Przemysław, Polska do wymiany. Późna nowoczesność i nasze wielkie narracje, W.A.B., Warszawa 2009.

Highmore Ben, Homework: Routine, Social Aesthetics and the Ambiguity of Everyday Life, "Cultural Studies" 2014, 18 (2-3), pp. 306-327.

Kozicka Dorota, Krytyki literackiej klopoty z politycznościa (w ostatnim 20-leciu), "Pamiętnik Literacki” 2009, issue 100/2, pp. 125-144. 
Moretti Franco, Distant Reading, Verso, New York 2013.

Moretti Franco, Graphs, Maps, Trees. Abstract Models for Literary History, Verso, London-New York 2007.

Polityka literatury. Przewodnik krytyki politycznej, [Kinga Dunin et al., introduction Przemysław Czapliński], Krytyka Polityczna, Warszawa 2009.

Rich Adrienne, Poetry and Commitment. An Essay, W.W. Norton \& Company, London-New York 2007.

Rich Adrienne, What is found there? Notes on Poetry and Politics, W.W. Norton \& Company, London-New York 1993.

Scully James, Line break. Poetry as social practice, Curbstone Books 2005.

Silliman Ron, The New Sentence, Roof Books, New York 2003.

Stokfiszewski Igor, Zwrot polityczny, Krytyka Polityczna, Warszawa 2009.

Ważyk Adam, Amfion, Czytelnik, Warszawa 1983.

Ważyk Adam, Dziwna historia awangardy, Czytelnik, Warszawa 1976.

Ważyk Adam, Esej o wierszu, Czytelnik, Warszawa 1964.

Ważyk Adam, W stronę humanizmu, Książka - Spółdzielnia Wydawnicza, Warszawa 1949.

\section{Marta Koronkiewicz}

\section{Polityka formy poetyckiej: Adam Ważyk i Amerykanie}

(Streszczenie)

Artykuł zestawia elementy metapoetyckiej, formalnej myśli Adama Ważyka - jednego z czołowych twórców i krytyków polskiej awangardy poetyckiej, zaangażowanego przez lata w ruch socjalistyczny - z refleksją na temat formy literackiej obecną u niektórych spośród najważniejszych amerykańskich krytyków literackich szkoły marksistowskiej: Adrienne Rich, Muriel Rukeyser, Rona Sillimana, Jamesa Scully’ego. Owi twórcy i twórczynie, wychodząc - podobnie jak Ważyk - z pozycji poetyckich praktyków (wszyscy pisali zarówno prozę krytyczną, jak i wiersze), stawiali w swojej twórczości nacisk na sprawczą moc poetyckiej formy - jej rolę dla praktyki literackiego wymyślania czy wprowadzania nowych rzeczywistości. To odróżnia ich w pewnym sensie od bardziej teoretycznie czy filozoficznie nastawionych nurtów marksistowskiego literaturoznawstwa, skupionych na formie jako epifenomenie sił społecznych.

Zestawiając myśl Ważyka z wymienionymi twórcami, artykuł wskazuje między innymi wspólne dla nich wszystkich rozumienie innowacji jako poszerzanie granic poetyckiego języka i radykalne zwiększanie możliwości komunikacyjnych.

Słowa kluczowe: poetyka, marksizm, polityczność poezji, Adam Ważyk, polityczność poezji. 


\title{
Marta Koronkiewicz
}

\section{Politics of the Poetic Form: Adam Ważyk and the Americans}

\begin{abstract}
(Summary)
The article discusses Adam Ważyk - one of the foremost representatives of the Polish poetic avant-garde - and his meta-poetic reflection on the form of the poem in comparison with the parallel considerations offered, later in the 20th c., by the American poets of the LANGUAGE movement. Most importantly, I mention Adrienne Rich, Muriel Rukeyser, Ron Silliman, and James Scully. These poets saw the poetic practice as part of the active and reconstructive approach to everyday reality, which is an approach that sets them apart from more theoretically predisposed strands of the Marxist literary theory which saw poetic forms mostly as an epiphenomenon of social forces and processes. The idea that is the strongest link between Ważyk and the American poets mentioned above is treating formal poetic innovation as precisely the element that serves the causes of enhancing the potential of language and communication.
\end{abstract}

Keywords: poetics, marxism, Adam Ważyk, innovation, poetic form, politics of poetics. 